\title{
Robust Soil Quality Index for Tropical Soils Influenced by Agricultural Activities
}

\author{
Jesus Gabriel Rangel-Peraza1, Edith Padilla-Gasca1, Rosalía López-Corrales ${ }^{1}$, \\ Jaime Rochín Medina1, Yaneth Bustos-Terrones ${ }^{2}$, Leonel Ernesto Amabilis-Sosa ${ }^{2}$, \\ Abraham Efraim Rodríguez-Mata ${ }^{2 *}$, Tomás Osuna-Enciso ${ }^{3}$
}

\author{
${ }^{1}$ Instituto Tecnológico de Culiacán, Departamento de Ing, Ambiental, Juan de Dios Batiz 310 Col. Guadalupe, \\ Culiacán, Mexico \\ ${ }^{2}$ CONACYT-Instituto Tecnológico de Culiacán, Juan de Dios Bátiz 310. Col. Guadalupe, P.C. 80220, Culiacán, \\ Sinaloa, México \\ ${ }^{3}$ Centro de Investigación en Alimentación y Desarrollo, A. C. Carretera Culiacán-El Dorado Km. 5.5 C.P. 80129, \\ Culiacán, México \\ Email: *Arodriguez@itculiaca n.edu.mx
}

\begin{abstract}
How to cite this paper: Rangel-Peraza, J.G., Padilla-Gasca, E., López-Corrales, R., Medina, J.R., Bustos-Terrones, Y., Amabilis-Sosa, L.E., Rodríguez-Mata, A.E. and Osuna-Enciso, T. (2017) Robust Soil Quality Index for Tropical Soils Influenced by Agricultural Activities. Journal of Agricultural Chemistry and Environment, 6, 199-221. https://doi.org/10.4236/jacen.2017.64014
\end{abstract}

Received: September 21, 2017

Accepted: November 17, 2017

Published: November 20, 2017

Copyright ( 92017 by authors and Scientific Research Publishing Inc. This work is licensed under the Creative Commons Attribution International License (CC BY 4.0).

http://creativecommons.org/licenses/by/4.0/

\section{(c) (i) Open Access}

\begin{abstract}
The knowledge of the soil quality plays a vital role in the agricultural sector. Despite its importance, there is scarce scientific information concerning this regard. The objective of this research is to develop a methodology to identify and select the most appropriate indicators of Soil Quality Index $(S Q I)$ in a region with high agricultural activity. For its conformation, a descriptive statistical analysis and a Pearson correlation matrix were performed and the indicators that showed greater variation were identified using a Principal Components Analysis (PCA). A sensitivity analysis was carried out and the most sensible soil indicators of $S Q I$ were identified. This statistical procedure was also used to specify the weights of the indicators in $S Q I$. The variables resulting from the multiparametric statistical analysis were $\mathrm{pH}$, organic matter, sodium, calcium, iron, zinc, cation exchange capacity and electrical conductivity. The robustness of the SQI obtained in this study was demonstrated through simulations carried out by the numerical optimization through simplex method. The Soil Quality Index range obtained $(0.54-0.75)$ locates Culiacan Valley soils as moderate/high quality.
\end{abstract}

\section{Keywords}

Principal Components Analysis, Soil Quality Index, Pearson Correlation, Soil Quality Indicators, Sensitivity Analysis 


\section{Introduction}

The geographic location, climate and topography of the state of Sinaloa have consolidated it as the most important region in Mexico for the production of food [1]. Its inhabitants base their economy on primary activities, especially those related to the field [2]. In Sinaloa, the most technified agriculture of the country is practiced, which allows to achieve high productivity. However, there is a serious concern that current agricultural practices used to increase crop yields are a determining factor in the degradation of the soils of the region.

Although knowledge of the soil quality plays a vital role in the improvement of the production and the productivity of the agricultural sector, there is scarce scientific information available about the magnitude of soil quality changes related to the different land uses [3]. In accordance with the Soil Science Society of America [4], soil quality is defined as the ability of soils to function within the boundaries of a natural or handled ecosystem, to sustain the productivity of plants and animals, to maintain or improve the quality of air and water, and to sustain human health and habitat.

The soil quality cannot be measured directly, but soil properties that are sensitive to changes under environmental and/or anthropogenic influences could be used as indicators of its quality [5]. These parameters could be qualitative or quantitative variables. Therefore they are used to develop indexes, which are composed by the relation between the different soil indicators. In general, these indicators refer to physical, chemical and biological properties of soils [6]. There is currently no agreement or established methodology for the selection of soil quality indicators. They should be selected on the basis of the climate, soil type, hydrology and other aspects of study area. Many indicators of soil quality have been proposed, but few have been tested and validated [7] [8].

According to this, the aim of this work is to develop a methodology to identify and select the most appropriate indicators for measuring the soil quality in a tropical region with high agricultural activity. Soil quality researches in tropical regions and even in Culiacan Valley are very limited, despite its importance in the food production [9] [10]. This work proposes a novel methodology to analyze and determine the correlation among the soil quality indicators of Culiacan Valley using the statistical analysis of the data. The study of soil indicators is relatively recent. Therefore, this study represents an opportunity area in the development of new knowledge for soil management. The development of a robust soil quality index is proposed, which could facilitate the process of decision-making and soil management at regional and international levels.

\section{Materials and Methods}

\subsection{Study Area}

The present research was carried out in the agricultural Valley of Culiacan, Sinaloa, Mexico. The municipality of Culiacan is located in the central region of the state of Sinaloa, between the meridian $106^{\circ} 56^{\prime} 50^{\prime \prime}$ and $107^{\circ} 50^{\prime} 15^{\prime \prime}$ West Lon- 
gitude and $24^{\circ} 02^{\prime} 10^{\prime \prime}$ and $25^{\circ} 14^{\prime} 56^{\prime \prime}$ Northern Latitude. The study area presents altitudes from sea level on the coast and reaches up to $2100 \mathrm{~m}$ in high areas. The climate is warm dry and the annual average temperature is $24^{\circ} \mathrm{C}$ to $26^{\circ} \mathrm{C}$. Total annual precipitation varies between 600 and $800 \mathrm{~mm}$. The vegetation present in the municipality varies: tropical deciduous forest is the dominant vegetation, but mangrove, xerophyte, scrub, oak forest, conifers and riparian vegetation could also be found [11] [12].

The Culiacan Valley is the most important agricultural zone of Sinaloa and is located within the Rural Development District (DDR) of Culiacan. The Culiacan agricultural area has approximately 140,000 ha with $60 \%$ of the land irrigated. The primary cyclic crops in the Culiacan area cover 132,000 ha and include corn, beans, sorghum, tomatoes, chilies, safflowers, chickpeas, and cucumbers [13].

The geological characteristics of the study area are: Pleistocene and geological formations of the beginning of the quaternary era are located in the coastal line. The central region is characterized by the rocky nature of the Cenozoic. Mountainous area consists mainly of metamorphic rocks of the mesozoic era. The soil is regosol feozem, vertisol, and Cambendazole, where most of the intended land is agricultural use [14].

\subsection{Sampling and Analysis of Soil Quality Indicators}

A surface sampling ( 0 - $0.3 \mathrm{~m}$ depth) of 23 different sites (Figure 1) was carried out during the period from August to December 2016 prior to the agricultural cycle. The samples were transported to the Laboratory of Plant Nutrition at Research Center for Food and Development (CIAD). After collection of soil samples, they were air-dried, grinded and passed through a $2 \mathrm{~mm}$ sieve to carry out the physical and chemical analysis. All analyses were performed in triplicate following standardized protocols.

The $\mathrm{pH}$ of each sample unit tested was determined by using a potentiometer in both the 1:2 soil to water mixture and the saturated paste methods [15]. Electrical conductivity (EC) was carried out with a multiparameter (Toledo, Seven Excellence) based on methodology proposed by Chi \& Wang [15]. Organic matter (OM) was determined by the Walkley \& Black method [16], inorganic nitrogen (Ninor) by distillation in micro-Kjeldahl [17] and available phosphorus (Pava) according to Bray and Kurtz method [18]. In addition, atomic absorption spectrometry with an Agilent Technologies 200 Series AA equipment were used for soil samples in order to determine the following elements [19]: sodium (Na), potassium $(\mathrm{K})$, calcium $(\mathrm{Ca})$, magnesium $(\mathrm{Mg})$, Iron $(\mathrm{Fe})$, manganese $(\mathrm{Mn})$, zinc $(\mathrm{Zn})$, copper $(\mathrm{Cu})$. Ions determination was carried out in this study in its exchangeable and soluble fraction [20]. The texture was also analyzed by Bouyoucos method [21]. Carbonate $\left(\mathrm{CO}_{3}\right)$, bicarbonate $\left(\mathrm{HCO}_{3}^{-}\right)$and chloride $\left(\mathrm{Cl}^{-}\right)$ were determined by volumetric titration and sulfates $\left(\mathrm{SO}_{4}^{2-}\right)$ was carried out by turbidimetry [22]. Cation Exchange Capacity (CEC), Percentage of Saturation (\%Sat) and Sodium Adsorption Ratio (SAR) were computed based on mathematical models reported by Visconti et al. [23]. 

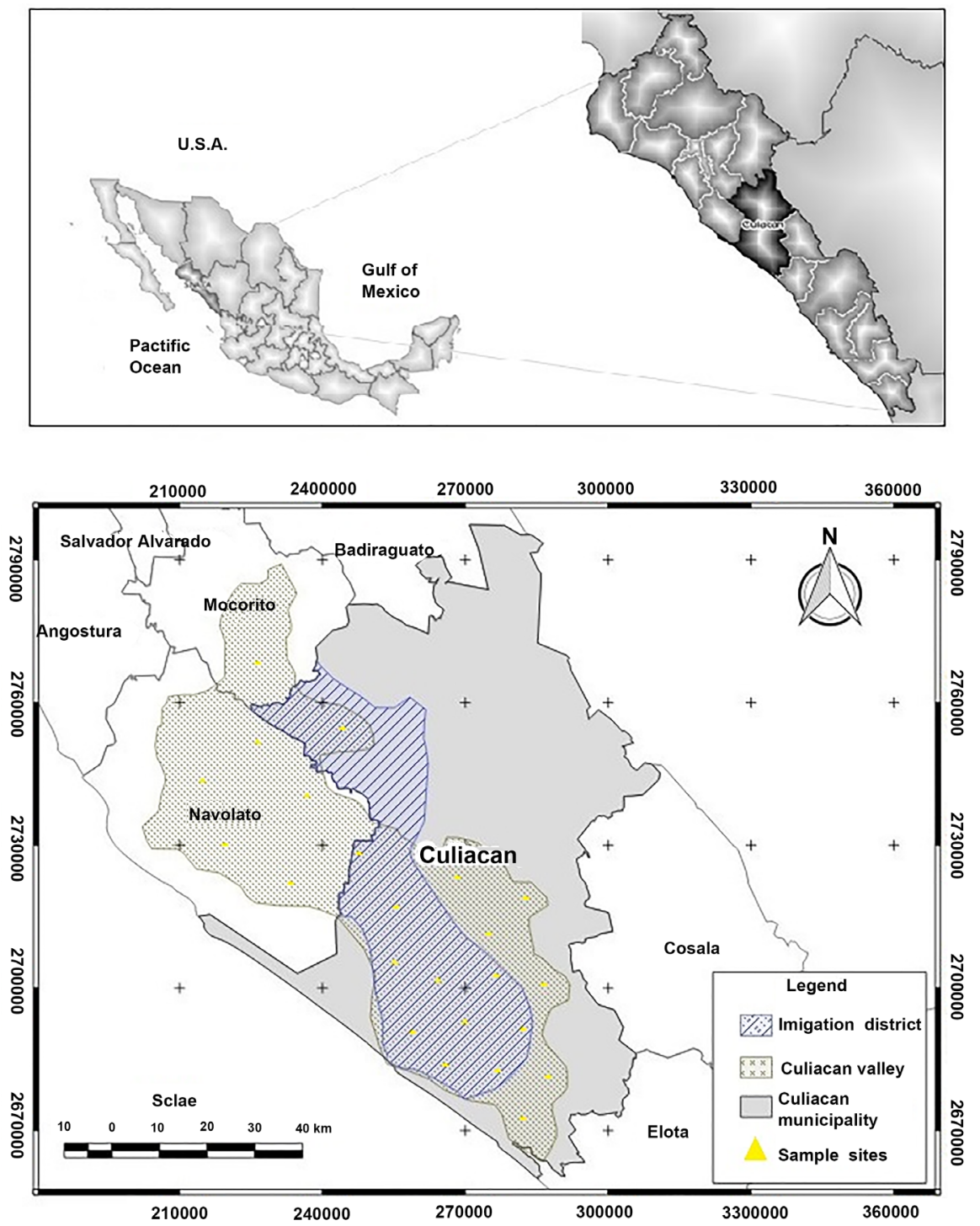

Figure 1. Geographic location of Culiacan Valley.

\subsection{Statistical Analysis}

In order to identify the soil quality indicators with greater influence in the study area, a statistical analysis was conducted. First, a descriptive analysis was carried out to observe the variability of the indicators and detect atypical values from a statistical point of view. The results were grouped for the purposes of analysis in two groups: fertility and salinity. Fertility group comprises the following soil indicators: $\mathrm{pH}$ 1:2, EC, OM, Ninor, Pava, CEC, texture and exchangeable fraction of $\mathrm{Na}, \mathrm{K}, \mathrm{Ca}, \mathrm{Mg}, \mathrm{Fe}, \mathrm{Mn}, \mathrm{Zn}$ and $\mathrm{Cu}$. Salinity group is comprised by pHsat (saturated paste method), EC, \% Sat, $\mathrm{CO}_{3}^{2-}, \mathrm{HCO}_{3}^{-}$and $\mathrm{Cl}^{-}$, SAR and soluble fraction of $\mathrm{Na}, \mathrm{K}, \mathrm{Ca}$ and $\mathrm{Mg}, \mathrm{Fe}, \mathrm{Mn}, \mathrm{Zn}, \mathrm{Cu}$.

Subsequently, a Pearson correlation matrix was developed with the purpose of finding the degree of correlation between the variables studied. Pearson correlation values fluctuate between 0 and 1 , where the magnitude of the relationship depends on the numerical value of this coefficient and the sign represents the 
type of correlation (positive or negative) [24]. Once the correlated variables were found, a Principal Components Analysis (PCA) was developed. This analysis reduced the existing data set, transforming it into a new set of variables (main components) which retain most of the variation present in the original variables [7] The indicators with the highest weights in the PCA will represent the parameters that have the greatest influence on the quality of the agricultural soils.

\subsection{Soil Quality Index (SQD) Development}

After these indicators were identified, the following mathematical model was used in order to calculate the Soil Quality Index (SQI) [25]:

$$
S Q I=\sum_{i=1}^{n} W_{i} S_{i}
$$

where:

$S_{i}=$ is the value of each indicator.

$W_{i}=$ is the relative weight of each indicator (weighted between 0 and 1).

According to Equation (1), soil indicators values $\left(S_{i}\right)$ were standardized. Standardization process was carried out because numeric values of the soil indicators are on very different scales of magnitude and even on different units. This research work proposes a novel methodology for the calculation of the functions used to obtain $S_{i}$ values in the $S Q I$ model. This contribution consists on using ideal frequency distributions (probability distributions) for each indicator used in the SQI. These probability distributions represent the ideal behavior of each soil indicator. These probability distributions were constructed based on suggested values for agriculture land use. To generate these distributions, the optimum value suggested for each indicator is only needed, with their respective maximum and minimum permissible limits. With this information, theoretical probability distributions were depicted.

Soil quality indicators and their respective weights $\left(W_{i}\right)$ are also usually given in SQI model (Equation (1)). Several authors have suggested $W_{i}$ values [18] [26] but most of these authors do not take into account the land use or study area characteristics. Another contribution of this work lies in the weighting of SQI indicators. Once the soil indicators that showed the greatest influence were identified from PCA analysis, the explained variation (\% variance) of these principal components was used to define $W_{i}$. This methodology is proposed to eliminate the subjective designation of $W_{i}$ in $S Q I$ model.

\subsection{Simulations and Sensitivity Analysis}

Once the relative weight of each indicator $\left(W_{i}\right)$ was found, Equation (1) was used to compute $S Q I$ values. According to this model, $S Q I$ values range between 0 and 1 . Soil could be classified in five soil classes [27]. SQI values between 0.8 and 1.0 could be considered as very high quality soils, while the values between 0.0 and 0.19 could be considered as very low quality soils.

Possible scenarios of $S Q I$ were simulated by using simplex numerical optimi- 
zation method. Some restrictions were introduced to the model: a) $W_{i}$ values must not exceed the variance obtained in PCA per component; b) During simulations, $W_{i}$ varied with a step size of 0.01 in order to obtain a finite number of solutions; c) $W_{i}$ values below 0.01 are not significant for establishing environmental indices [28]. Once the theoretical distribution of $S Q I$ values were obtained, the most probable $S Q I$ value was identified and optimal $W_{i}$ values for each indicator of $S Q I$ were obtained.

Finally, a sensitivity analysis was performed to identify the indicators that have the greatest influence on $S Q I$ model [25]. Sensitivity analysis consisted of fluctuating each of the soil indicators previously selected. Soil indicator values decreased and increased within a defined percentage $(+/-50 \%$ and $+/-20 \%$ for all indicators, respectively). The output deviations of $S Q I$ values reflect the response sensitivity, which represents the differences produced in each experiment and defines the indicators of the model that have greater influence.

The soil quality index model sensitivity was calculated using a sensitivity coefficient $(S C)$. This arises from the quotient divided by the change percentage in the model output variable ( $S Q I$ value) with respect to the change percentage in the input variable (soil indicator), as shown in Equation (2):

$$
S C=\frac{\% \text { change in the } S Q I \text { value }}{\% \text { change in the soil indicator }}
$$

With this information, most sensitive soil indicators were identified and a robust index was developed and validated. Robust soil quality index could be defined as a set of soil indicators statistically obtained, which consistently (low variation) explain soil quality in a specific area according to its land use.

\section{Results and Discussion}

\subsection{Descriptive Analysis}

The statistical analysis of the soil quality indicators began with a descriptive analysis of the results obtained in the laboratory. Table 1 shows the main descriptive statistics (mean, standard error, range) for each of the soil quality indicators analyzed. A detailed analysis of each indicator is presented below:

1) $\mathrm{pH}$

The $\mathrm{pH}$ of the soil has a great impact on the solubility of the elements and the availability of nutrients. The adsorption processes, mineral dissolution of acid functional groups, and the cation exchange capacity depend on the $\mathrm{pH}$. The $\mathrm{pH}$ affects the microbial diversity and activity, which in turn, significantly affects the decay rates of plant residues, affecting the content of organic matter in the soil [29]. The $\mathrm{pH}$ is an indicator of an abnormal situation in soils, when it reaches boundary values. When the $\mathrm{pH}$ is out of its optimal limits, this situation indicates a compact soil, subject to erosion [30]. In the present study, an average $\mathrm{pH}$ value of 7.44 was obtained, which is considered as moderately alkaline according to FAO [31]. The minimum $\mathrm{pH}$ value obtained was 4.72 , considered acid; while the maximum value was 9.01 , classified as alkaline; both values were reported 
Table 1. Measures of central tendency and dispersion for the soil quality indicators.

\begin{tabular}{|c|c|c|c|c|c|}
\hline & Parameter & Unit & Mean & Standard error & Range \\
\hline & $\mathrm{pH}_{1: 2}$ & $\left(25^{\circ} \mathrm{C}\right)$ & 7.44 & 0.18 & 4.29 \\
\hline & $\mathrm{EC}$ & $(\mathrm{dS} / \mathrm{m})$ & 1.30 & 0.44 & 8.22 \\
\hline & Org matter & (\%) & 1.38 & 0.19 & 3.83 \\
\hline & $\mathrm{N}$ inor & $(\mathrm{mg} / \mathrm{L})$ & 24.22 & 2.49 & 41.91 \\
\hline & $\mathrm{P}$ ava & $(\mathrm{mg} / \mathrm{L})$ & 64.56 & 16.87 & 305.59 \\
\hline & $\mathrm{Na}^{*}$ & $(\mathrm{mg} / \mathrm{L})$ & 557.81 & 137.40 & 2635.78 \\
\hline & $\mathrm{K}^{*}$ & $(\mathrm{mg} / \mathrm{L})$ & 427.88 & 66.59 & 1214.11 \\
\hline & $\mathrm{Ca}^{*}$ & $(\mathrm{mg} / \mathrm{L})$ & 5182.47 & 574.09 & 12635 \\
\hline \multirow[t]{14}{*}{ Fertility } & $\mathrm{Mg}^{*}$ & $(\mathrm{mg} / \mathrm{L})$ & 845.85 & 82.75 & 1494.21 \\
\hline & $\mathrm{Fe}^{\star}$ & $(\mathrm{mg} / \mathrm{L})$ & 23.22 & 5.12 & 124.42 \\
\hline & $\mathrm{Mn}^{*}$ & $(\mathrm{mg} / \mathrm{L})$ & 36.45 & 8.20 & 147.15 \\
\hline & $\mathrm{Zn}^{*}$ & $(\mathrm{mg} / \mathrm{L})$ & 2.78 & 1.42 & 34.35 \\
\hline & $\mathrm{Cu}^{*}$ & $(\mathrm{mg} / \mathrm{L})$ & 1.99 & 0.27 & 4.36 \\
\hline & CEC & (meq/100g) & 36.34 & 3.54 & 70.95 \\
\hline & Clay & $(\%)$ & 44.37 & 3.57 & 60.88 \\
\hline & Silt & (\%) & 28.35 & 3.23 & 60.88 \\
\hline & Sand & (\%) & 27.57 & 3.59 & 66.72 \\
\hline & $\mathrm{pH}$ sat & $\left(25^{\circ} \mathrm{C}\right)$ & 8.02 & 0.14 & 3.45 \\
\hline & $\%$ sat & (\%) & 50.22 & 3.20 & 60 \\
\hline & $\mathrm{Na}^{\circ}$ & $(\mathrm{meq} / \mathrm{L})$ & 5.42 & 1.78 & 33.47 \\
\hline & $\mathrm{K}^{\circ}$ & $(\mathrm{meq} / \mathrm{L})$ & 0.48 & 0.10 & 2.27 \\
\hline & $\mathrm{Ca}^{\circ}$ & $(\mathrm{meq} / \mathrm{L})$ & 7.95 & 2.95 & 55.15 \\
\hline \multirow[t]{6}{*}{ Salinity } & $\mathrm{Mg}^{\circ}$ & $(\mathrm{meq} / \mathrm{L})$ & 3.35 & 1.29 & 22.5 \\
\hline & SAR & * & 2.55 & 0.54 & 10.18 \\
\hline & $\mathrm{CO}_{3}$ & $(\mathrm{meq} / \mathrm{L})$ & 0.20 & 0.05 & 0.8 \\
\hline & $\mathrm{HCO}_{3}$ & $(\mathrm{meq} / \mathrm{L})$ & 4.06 & 0.64 & 14.7 \\
\hline & $\mathrm{Cl}$ & $(\mathrm{meq} / \mathrm{L})$ & 7.72 & 3.44 & 67.26 \\
\hline & $\mathrm{SO}_{4}$ & (meq/L) & 0.49 & 0.15 & 3.46 \\
\hline
\end{tabular}

*: Extractable ions; ${ }^{\circ}$ : Soluble ions.

only in one sample site for each value. The acid soil sample was associated with nutrient deficiencies of calcium, magnesium and potassium, with a solubility increase of zinc, copper and iron. The alkaline soil sample was related to nutrient deficiencies of trace elements, in particular iron and zinc, as well as phosphorus deficiency. This situation is similar to the reported by Lal [32].

2) Texture

Texture is one of the most stable soil properties and determines the agricultural potential of the soil. This indicator is directly related to retention water ca- 
pacity of soil, aeration properties, the ease of soil cultivating and it also affects the fertility of the soil. Texture affects the ability of the soil to retain the organic matter. Gelman et al. [16] observed that the concentration of organic matter was greater in the fractions of fine silt and clay.

In this study, soil composition showed that the average percentages of clay, silt and sand were $44.37 \%, 28.35 \%$ and $27.57 \%$, respectively. This soil composition agrees with the composition reported for vertisol type soil classification [31], which is predominant in Culiacan Valley. This type of soil is particular in tropical and subtropical climates, where a clear change between rainy and dry season is observed. According to soil composition registered in this study, these soils have considerable agricultural potential [1].

3) Saturation Percentage

Saturation percentage is the maximum amount of water the soil can retain against gravity force. This indicator is affected by soil composition, in particular by the amount and type of clays present and the content of organic matter. In accordance with Zhao \& Zhang [33], the soils with high content of coarse sand have a saturation percentage less than $10 \%$, while very clayey soils (organic soils) present percentages of saturation of up to $150 \%$.

The mean saturation percentage in the present study was of $50.22 \%$. This is due to the nature of the soil clay in study area [34]. Saturation percentages ranged from $85 \%$ to $25 \%$. This analysis is rarely carried out by laboratories of soil quality, therefore the information about this indicator is limited.

4) Organic matter

Organic matter is the soil fraction composed of everything that was once alive. This includes remains of plants and animals at various stages of decomposition, cells and tissues of various living organisms and other organic substances. The content of organic matter makes the soil more friable and easier to work with. Organic matter stabilizes and keeps the soil particles together in aggregates, thereby reducing erosion. To improve the distribution of the size of the pores and decrease the bulk density, organic matter also improves the ability of soil to store and transmit the air and water [16].

The average percentage of organic matter obtained in the samples was $1.38 \%$. In accordance with the requirements to maintain the fertility of the soil [31], this value is considered as slightly deficient. The minimum content of organic matter was $0.11 \%$ and a maximum of $3.94 \%$. This low organic matter content can be attributed to the low amount of organic materials applied to the soil and to the complete removal of the biomass in the field, as it was observed by Pansu et al. [12]. On the other hand, Lal \& Stewart [3] suggest that continuous and intensive cultivation practices can explain the deterioration of the soil aggregates, combined with the low return of plant biomass to the soil in cultivated land.

5) Inorganic Nitrogen

Nitrogen is one of the most limiting factors in the growth of plants. This element is distributed in the soil in different phases: inorganic and organic nitrogen. The organic forms of nitrogen are derived from the decomposition of or- 
ganic matter and constitute the predominant forms in the soil (approximately $95 \%$ of the total $\mathrm{N}$ ). Through the process of mineralization, organic nitrogen becomes gradually available to plants, being the nitrate $\left(\mathrm{NO}_{3}^{-}\right)$and ammonium $\left(\mathrm{NH}_{4}^{+}\right)$the available forms of nitrogen.

The maximum $(48.88 \mathrm{mg} / \mathrm{L})$ and minimum $(6.97 \mathrm{mg} / \mathrm{L})$ concentration of inorganic nitrogen observed of inorganic nitrogen correspond to those samples representing the maximum and minimum values for the organic matter content, respectively. Therefore, inorganic nitrogen was highly related to mineralization process, which in turn is influenced by different factors, such as the organic matter content and $\mathrm{pH}$. The average inorganic nitrogen value obtained for the analyzed samples was $24.22 \mathrm{mg} / \mathrm{L}$, which suggests a suitable value, taking as reference the requirements for cultivation of maize [35].

6) Phosphorus

In most of terrestrial ecosystems, the absorption of phosphorus by plants is limited by the low total amount of phosphorus in the soil and/or by the low solubility of this element. The available P fraction of the soil is less than $1 \%$ and it is mainly controlled by chemical reactions rather than by biological processes. According to Merrington \& Schoeters [36], vertisol soils are generally low in total phosphorus. However, the results obtained in this study do not agree with this asseveration. The average content of phosphorus was of $64.56 \mathrm{mg} / \mathrm{L}$. The mean concentration of total phosphorus found in Culiacan Valley can be considered as high, according to the classification given by Athokpam et al. [37]. The elevated values of phosphorus present in soils may be due to the application of phosphate fertilizers in crop land, as a way to compensate for the natural deficiencies of this element. This situation is demonstrated by the high variation recorded for this indicator, which ranged from $0.01 \mathrm{mg} / \mathrm{L}$ to $305.6 \mathrm{mg} / \mathrm{L}$.

7) Electrical conductivity

Electrical conductivity is an indirect measure of the amount of total soluble salts and the degree of salinity that a soil contains. This indicator depends on the climatic conditions of the area. For soils located in subhumid tropics, there is enough precipitation to remove ground surface, forming cations in the root zone. Therefore, the electrical conductivity is usually less than $4 \mathrm{dS} / \mathrm{m}$. On the contrary, the soils of arid climates are characterized by salinization due to the lack of adequate precipitation for washing and transporting the salts, and the high evaporation, which tends to concentrate those [38].

Soils with high electrical conductivity hamper the good development of the plants, because they contain a high amount of salts. To distinguish non-saline soils, salinity limits have been suggested. It is accepted that the plants are adversely affected when the salts content exceeds $1 \%$. The American Soil classification (Soil Taxonomy) suggests the value of $2 \mathrm{dS} / \mathrm{m}$ as a maximum soil salinity value, while the U.S. Salinity Laboratory has established the limit of $4 \mathrm{dS} / \mathrm{m}$ to begin being toxic to plants [39].

The average soil electrical conductivity under study was $1.30 \mathrm{dS} / \mathrm{m}$, a value that is below the limits suggested by Soil Taxonomy. Apparently this indicator 
also presented a high variation from $0.2 \mathrm{dS} / \mathrm{m}$ to $8.42 \mathrm{dS} / \mathrm{m}$, however more than $90 \%$ of the electric conductivity values in the study area were lower than $1 \mathrm{dS} / \mathrm{m}$. In this sense, the maximum and minimum values obtained correspond to atypical samples of soils located in Culiacan Valley.

8) Exchangeable Cations

Exchangeable cations are ions with positive electrical charge that are weakly adsorbed by soil particles. They could be moved or replaced from the particle surface, from the soil to the solution phase, by another ion. The main exchangeable cations are $\mathrm{Ca}^{2+}, \mathrm{Mg}^{2+}, \mathrm{K}^{+}$and $\mathrm{Na}^{+}$. The typical proportions of these cations in soils are $80 \% \mathrm{Ca}^{2+}, 15 \% \mathrm{Mg}^{2+}, 5 \%\left(\mathrm{Na}^{+}\right.$and $\left.\mathrm{K}^{+}\right)$, with small variable quantities of $\mathrm{NH}_{4}^{+}$, depending on the magnitude of the nitrification process in the soil [36]. Given that the soils of tropical regions are highly degraded, the quantities of exchangeable cations are limiting factors in agricultural productivity [40]. As a result of this, acidification of soil upper layers is observed. In this study, the exchangeable and soluble fractions of those elements were obtained in soil. Masto et al. [41] suggests soluble fraction determination since exchangeable concentration of these microelements does not represent its availability for plants. Plants can only reach and absorb a fraction of these cations. Therefore, soluble fraction determination measure the minerals that are in solution and that could be reached by the root [42].

Exchangeable calcium concentration mean value of $5182.47 \mathrm{mg} / \mathrm{L}$ was observed, with soluble calcium mean value of $7.95 \mathrm{meq} / \mathrm{L}$. Soluble fraction of calcium was slightly below the optimum levels for crop $(9.98 \mathrm{meq} / \mathrm{L})$ reported in the literature [42]. Besides, this indicator presented the greatest variability of all cations analyzed due to the particular characteristics of each sampling site.

The mean content of exchangeable magnesium was $845.85 \mathrm{mg} / \mathrm{L}$, in which the soluble fraction was $3.35 \mathrm{meq} / \mathrm{L}$. This value is almost three times the concentration considered to be optimal for good productivity [42] In the case of potassium, mean values of $427.88 \mathrm{mg} / \mathrm{L}$ and $0.48 \mathrm{meq} / \mathrm{L}$ were obtained for exchangeable concentration and soluble fraction, respectively. Based on these results, potassium could be considered as a limiting factor in agricultural soils of the region. Average potassium concentration was below the potassium values recommended $(0.51 \mathrm{meq} / \mathrm{L})$ for crops [42]. Finally, taking into consideration the average concentration of exchangeable sodium $(557.81 \mathrm{mg} / \mathrm{L})$ and soluble sodium (5.42 meq/L), the soils in the area of study can be classified as soils with an average salinity.

9) Cation Exchange Capacity

The cation exchange capacity (CEC) is an expression of soil negative charge. It is measured as the total number of equivalent of cations displaced per mass unit of soil by an extraction solution that contains a high concentration (typically 1.0 M) of a cation of removal. It is desirable that the soil present a high cation exchange capacity, as it represents soil capacity to retain the elements necessary for plants. This parameter also indicates the soil potential to provide calcium, magnesium and potassium to plants [43]. In the present study, the samples showed a 
high cation exchange capacity, with an average value of $36.34 \mathrm{meq} / 100 \mathrm{~g}$, and are hence considered as soil with great natural fertility [44].

a) Micronutrients

Micronutrients are essential for maintaining the productivity of the soils located at tropical latitudes. Continuous fertilization of crops without the inclusion of micronutrients can cause soils deficient in these nutrients. Despite its importance, the information about the availability of micronutrients is scarce. The concentration of micronutrients in soil is determined by various intrinsic factors such as soil texture, organic matter content, $\mathrm{pH}$, moisture content, among others. In particular, copper, manganese, zinc and iron are affected by $\mathrm{pH}$ and redox potential of the soil and its availability may vary from one day to another [45].

Mean zinc concentration in Culiacan Valley soils was $2.78 \mathrm{mg} / \mathrm{L}$, almost three times above the optimal value of this element $(1.0 \mathrm{mg} / \mathrm{L})$, according to FAO [31]. In the case of copper, the soils analyzed showed a mean value of $1.99 \mathrm{mg} / \mathrm{L}$, which was above the reference value suggested by FAO [31] for this micronutrient $(0.6 \mathrm{mg} / \mathrm{L})$. The elements considered as micronutrients in the soil, which presented a higher concentration were the manganese and iron, with values of $36.45 \mathrm{mg} / \mathrm{L}$ and $23.22 \mathrm{mg} / \mathrm{L}$, respectively. Both elements also had concentrations above the suggested as optimal for crops. The variability observed in the available concentrations was largely due to variation in soil parent material, rainfall and soil management [46].

b) Anions

In agricultural soils, the existence of a balance in the electrical charges is necessary. This situation imposes restrictions on the absorption of nutrients from the soil by plants. In this sense, there must be a balance of anions and cations in the soil and in the plant. The plants use inorganic anions to form proteins and other organic molecules. The main salts present in the soil that plants require are in the form of anions: carbonate $\left(\mathrm{CO}_{3}^{2-}\right)$, bicarbonate $\left(\mathrm{HCO}_{3}^{-}\right)$, chloride $\left(\mathrm{Cl}^{-}\right)$ and Sulfate $\left(\mathrm{SO}_{4}^{2-}\right)$.

Carbonates and bicarbonates in soils are derived directly from the sedimentary rock and occasionally are formed by alteration of the minerals present in the bedrock. In both cases, the source of carbonates is native. However, there are external sources of these compounds, for example, due to transport by wind or water (allochthonous sources). These compounds are affected by edaphic processes in such a way that the carbonates accumulate successively in specific horizons as a function of time.

The presence of these compounds is an indicator of the buffering capacity of the soil. In particular, these compounds prevent soil become acid and reduce the concentration of soluble elements that are toxic to the root system of many plants, such as aluminum (Al) [47]. The mean concentration of bicarbonates in the present study was $4.06 \mathrm{meq} / \mathrm{L}$, whereas the mean concentration of carbonate was of $0.20 \mathrm{meq} / \mathrm{L}$. Bicarbonates and carbonates problems have been found in arid regions, where the soils tend to be saline with high levels of these salts. Be- 
cause salts move with the water, the problems of salt are almost always temporary. Toxicity by high concentrations of these salts may occur, but usually these salts are washed in a natural way before the soil is analyzed. Hence, low values of bicarbonates and carbonates do not always discard toxicity [21]. Unfortunately it is not a common practice to analyze the content of these salts in the soil, and there are very few data to interpret the results.

On the other hand, the mean concentration of $\mathrm{Cl}^{-}$in the soil samples was $7.72 \mathrm{meq} / \mathrm{L}$. The literature reports that plants require this anion in small concentrations, no greater than $0.5 \mathrm{meq} / \mathrm{L}$ [43]. Taking into account this value, the concentrations of this anion were above values considered optimal. High concentrations of chloride can cause toxicity problems and result in reduced performance of soil for agricultural purposes. The high concentrations reported of $\mathrm{Cl}^{-}$in the present study can be attributed to the use of certain fertilizers in this region, particularly $\mathrm{KCl}, \mathrm{CaCl}_{2}, \mathrm{NH}_{4} \mathrm{Cl}$ or $\mathrm{MgCl}_{2}$ compounds. According to this, the presence of chloride ion can become a limiting factor for the growth of the crops in the study area.

Sulfur is assimilated by plants as ion sulfate $\left(\mathrm{SO}_{4}^{2-}\right)$. Sulfur-deficient soils do not support good growth of plants, largely because the sulfur is a component of some essential amino acids [47]. In the present study, the average concentration of sulfate in soils was low, with a mean value of $0.49 \mathrm{meq} / \mathrm{L}$. This value is considered low as suggested by Ortega [42]. The continuous use of fertilizers deficient in sulfur can lead to this element to be a limiting nutrient. On the other hand, the geographical location of the study area may justify the low concentration of sulfates found, given that this anion can be reduced through reactions with organic matter carried out by sulfate-reducers microorganisms [22] [48].

\subsection{Pearson's Correlation Analysis}

Linear relationship between some of the soil indicators are reflected in Table 2 . Soil quality indicators that had direct relationship were the exchangeable cations $\left(\mathrm{Ca}^{2+}, \mathrm{Na}^{+}, \mathrm{Fe}^{3+}\right.$ and $\left.\mathrm{Zn}^{2+}\right)$ and soluble cations and anions $\left(\mathrm{Ca}^{2+}, \mathrm{Na}^{+}, \mathrm{K}^{+}, \mathrm{Mg}^{2+}\right.$, $\left.\mathrm{SO}_{4}^{2-}\right)$. The relationship found between these elements is logical to assume, as they represent different fractions of the same nutrients present in the soil. It is noteworthy that the soil indicator that showed most of relationships with other indicators was electrical conductivity. This parameter observed high positive correlation with $\mathrm{Na}$ (0.91), $\mathrm{Ca}(0.94), \mathrm{Mg}(0.98), \mathrm{Cl}^{-}(0.92)$ and $\mathrm{SO}_{4}^{2-}(0.87)$. In case of $\mathrm{pH}$, this indicator showed a negative correlation with $\mathrm{Fe}^{3+}(0.69)$ and $\mathrm{Zn}^{2+}(0.70)$. In general, most of the relationships found in this statistical analysis were related to cations or anions present in soil.

\subsection{Principal Components Analysis}

A Principal Components Analysis (PCA) was conducted only with the indicators that showed direct correlation among them. The eigenvalues, the proportion of variance explained (\% variance) and the cumulative variance of each component constructed is shown in PCA analysis (Table 3). Variance explained data is very 


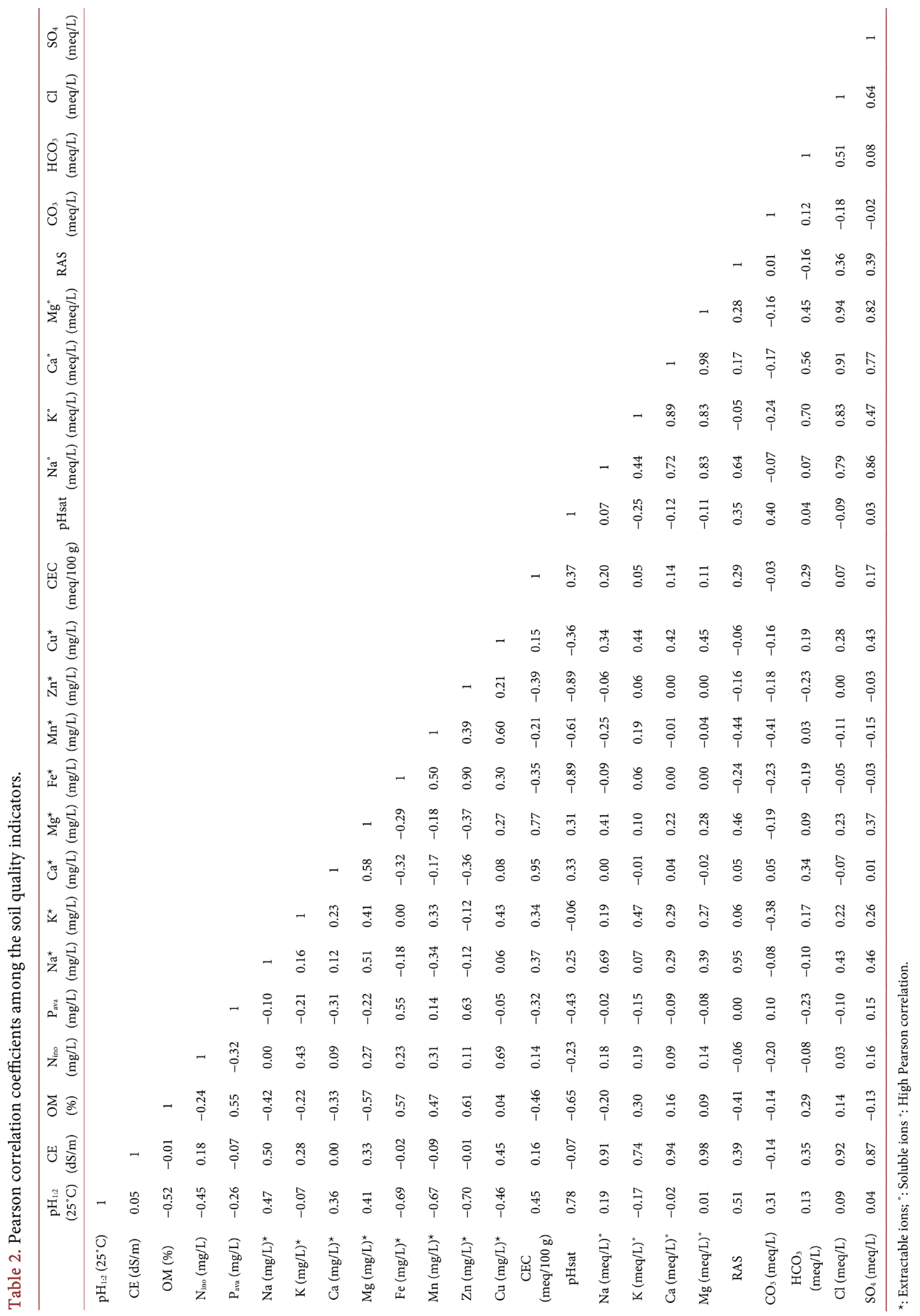


Table 3. Principal components analysis with their respective soil quality indicators.

(a)

\begin{tabular}{cccc}
\hline Component & Eigenvalue & \% Variance & \% Accumulated \\
\hline 1 & 7.09 & 47.28 & 47.28 \\
2 & 3.58 & 23.89 & 71.17 \\
3 & 1.69 & 11.28 & 82.45 \\
4 & 1.42 & 9.45 & 91.90 \\
\hline
\end{tabular}

(b)

\begin{tabular}{ccccc}
\hline Indicator & Component 1 & Component 2 & Component 3 & Component 4 \\
\hline $\mathrm{EC}$ & $0.371^{+}$ & -0.060 & 0.038 & -0.015 \\
$\mathrm{Na}^{*}$ & 0.222 & 0.196 & $-0.490^{+}$ & 0.148 \\
$\mathrm{Ca}^{*}$ & 0.024 & $0.323^{+}$ & 0.294 & $0.573^{+}$ \\
$\mathrm{Fe}^{*}$ & -0.040 & $-0.444^{+}$ & -0.163 & $0.348^{+}$ \\
$\mathrm{Zn}^{*}$ & -0.030 & $-0.444^{+}$ & -0.222 & $0.321^{+}$ \\
$\mathrm{CEC}$ & 0.091 & $0.350^{+}$ & 0.161 & $0.566^{+}$ \\
$\mathrm{pHsat}^{\circ}$ & 0.011 & $0.478^{+}$ & 0.030 & $-0.300^{+}$ \\
$\mathrm{Na}^{\circ}$ & $0.349^{+}$ & 0.033 & -0.212 & -0.006 \\
$\mathrm{~K}^{\circ}$ & 0.268 & -0.169 & $0.374^{+}$ & -0.022 \\
$\mathrm{Ca}^{\circ}$ & $0.343^{+}$ & -0.105 & 0.238 & -0.014 \\
$\mathrm{Mg}^{\circ}$ & $0.362^{+}$ & -0.097 & 0.131 & -0.041 \\
$\mathrm{RAS}$ & 0.187 & 0.225 & $-0.548^{+}$ & 0.052 \\
$\mathrm{Cl}$ & $0.346^{+}$ & -0.083 & 0.087 & -0.085 \\
$\mathrm{SO}_{4}$ & $0.320^{+}$ & -0.014 & -0.052 & -0.003 \\
\hline
\end{tabular}

*: Extractable ions; ${ }^{\circ}$ : Soluble ions; ${ }^{+}$: Contribution (importance) of soil indicator in each individual component

important to define the amount of components that will be used in the SQI. There are no rules about the number of components to be used. This must be decided according to the total number of $S Q I$ variables. PCA analysis was carried out to reduce the amount of response variables. Synthetic variables (components) were created, where four different linear combinations explain a total of $91.90 \%$ of the variability observed.

PCA also shows the correlations of the main components with each variable: this allows interpreting the new variables generated. In this study, Principal Component 1 (PC1) had a higher positive correlation with the electrical conductivity, $\mathrm{Mg}, \mathrm{Na}$ and $\mathrm{Cl}$. Therefore, PC1 refers to soil salinity. Principal Component 2 (PC2) showed a positive correlation with $\mathrm{pH}$ and a negative correlation with $\mathrm{Fe}$ and $\mathrm{Zn}$. In this case, $\mathrm{PC} 2$ is referring to soil fertility related to the presence of micronutrients. PC3 had a high positive correlation with sodium and the sodium adsorption ratio (SAR). This component reflects the possible influence of sodium ion on soil properties, particularly in the formation of colloids and 
their permeability. Finally, PC4 exhibited a high correlation with $\mathrm{Ca}$ and cation exchange capacity (CEC). This component represents the cations that the soil can retain. This component (PC4) represents the soil capacity to retain and exchange nutrients.

\subsection{Soil Quality Index (SQI)}

Soil indicators that presented the highest correlations in the PCA and those indicators that showed a greater variation during the descriptive analysis were taken into account to conform to $S Q I$. Electrical conductivity and Ca were chosen from PC. Fe, $\mathrm{Zn}$ and $\mathrm{pH}$ were chosen as $S Q I$ indicators from PC2. Due to the characteristics of PC3, only Na was chosen. Finally the CEC was chosen from of PC4. Organic matter was also included in the $S Q I$ due to the high variation presented in the study area and due to its importance based on several soil quality studies [18] [24]. Despite SAR showed a great weight in the PCA, this soil indicator was discarded due to the scarce information about this indicator in literature.

Once $S Q I$ was constructed from those indicators that presented the highest relationship in PCA and showed the highest variation in descriptive analysis, the indicators were standardized in a scale of 0 to 1 . Standardization process could be defined as a transformation of soil indicators previously selected to a similar scale in order to compare them [49]. This standardization represents the worst and best condition of the soil quality, based on the mean value registered for each indicator. Probability distributions were used to standardize the indicator score $\left(S_{i}\right)$ in accordance with specific criteria for each indicator. For the $\mathrm{pH}$, a criterion was based on the suggested $\mathrm{pH}$ value of this indicator for Vertisol soil type [50]. In the case of organic matter and electrical conductivity, the reference values were considered those suggested by Masto et al. [41] to classify soil as medium saline. In the case of the cation exchange capacity and $\mathrm{Ca}$, the values reported as good for cultivation were taken as it was reported by Hanum et al. [17]. Finally, Fe and $\mathrm{Zn}$ optimal values were based on those reported in Ortega [42], which are considered as minimal before they cause deficiencies in the crop. Probability distributions used to standardize soil quality indicators are given in Figure 2.

On the other hand, the proportion of variance explained (\% variance) of the components obtained during the PCA served as a basis to define the weighting factors of each indicator during the construction of SQI. According to Table 3, PC1 explains $47.28 \%$ of the total variance. Therefore, the weights assigned for the indicators that were selected from that component add up to that variation. With this criterion, weights were assigned to all soil quality indicators.

\subsection{Simulation and Sensitivity Analysis Results}

During simulation, the aforementioned restrictions were established and weights of each indicator $\left(W_{i}\right)$ were varied. Simplex optimization algorithm was used in order to obtain the maximum and minimum SQI values. 140 possible solutions 

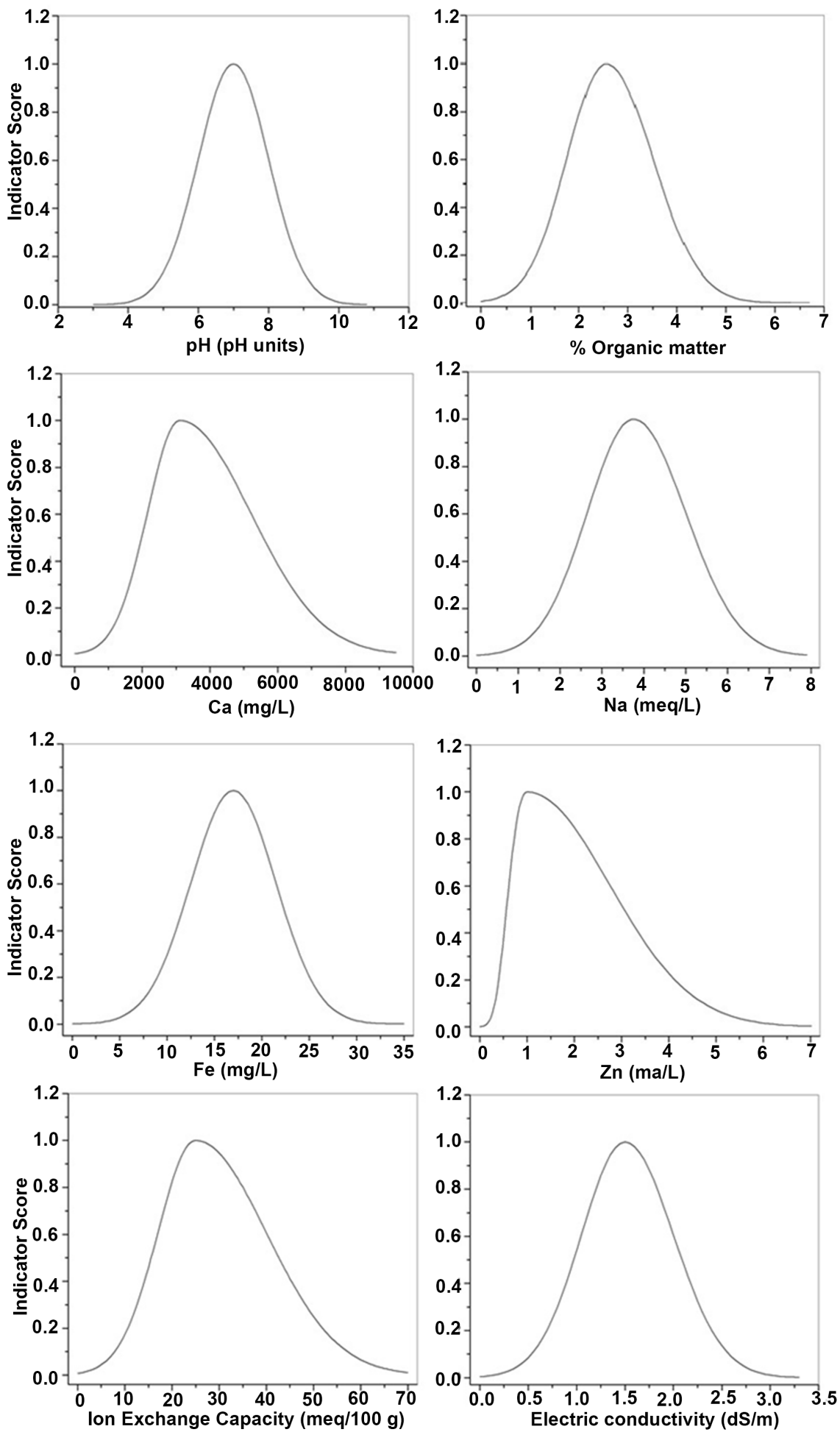

Figure 2. Probability distributions used to standardize the indicator score $\left(S_{i}\right)$.

were found (Figure 3). The results obtained showed a normal probability distribution. The mean $S Q I$ value was similar to median value, with values of 0.6523 and 0.6525 respectively. Therefore, mean $S Q I$ value obtained could represent the most probable $S Q I$ value in this study area. Based on this $S Q I$ 


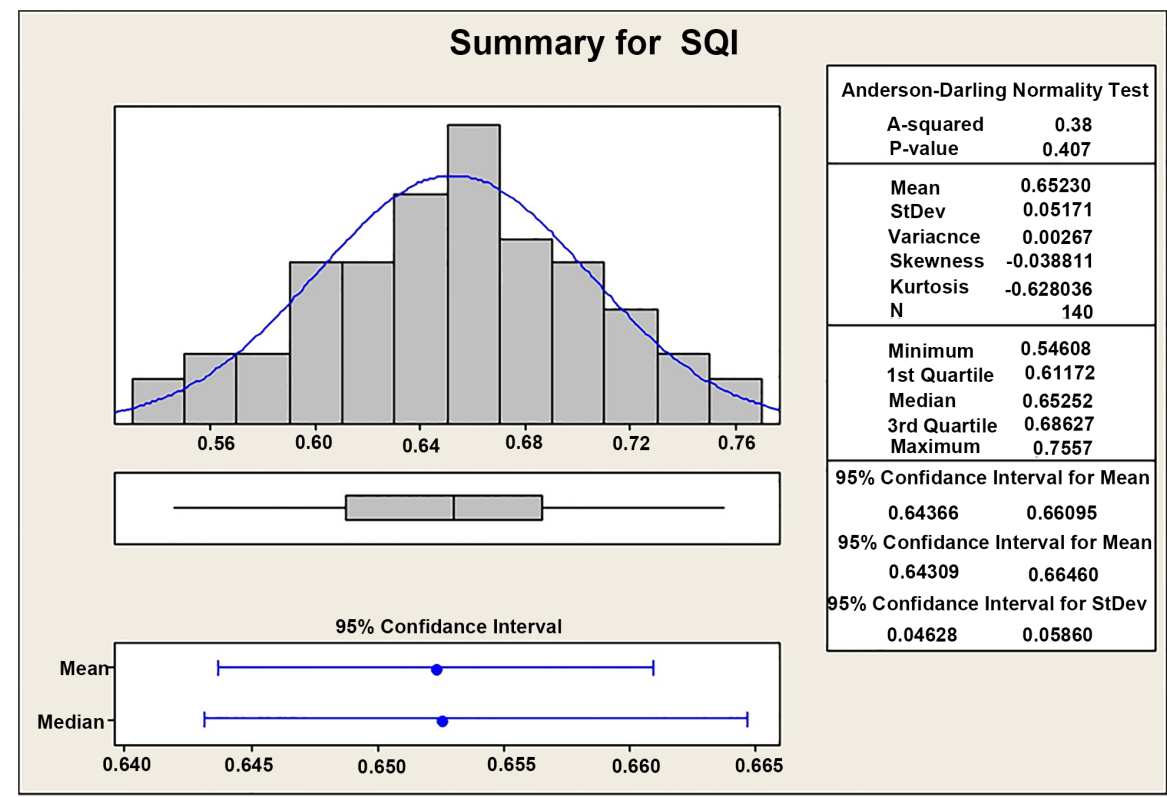

Figure 3. Soil Quality Index scenarios.

value, weight indicator values could be obtained. These weights were: $\mathrm{W}_{\mathrm{pH}}=$ $0.01, \mathrm{~W}_{\mathrm{Na}}=0.11, \mathrm{~W}_{\mathrm{Fe}}=0.14, \mathrm{~W}_{\mathrm{Zn}}=0.09, \mathrm{~W}_{\mathrm{CEC}}=0.09, \mathrm{~W}_{\text {OrgMatter }}=0.081$, $\mathrm{W}_{\mathrm{EC}}=0.35$ and $\mathrm{W}_{\mathrm{Ca}}=0.12$. The sum of these values corresponds to 1.0. Relative weights $\left(W_{i}\right)$ and values of each indicator $\left(S_{i}\right)$ are shown in Table 4.

$S Q I$ simulation results showed a standard deviation of 0.0517 . This statistical parameter indicates that $S Q I$ varied $7.92 \%$ from the mean value. Although weight values were varied as much as possible, $S Q I$ variation was slight. These results demonstrated the statistical robustness of the index [51]. Soil quality index values in the agricultural Valley of Culiacan range from 0.54 to 0.76 . Based on these values, soils under study could classify as medium and high quality.

Figure 4 shows the indicators effects during the sensitivity analysis of the soil quality model. The most significant parameters that affect the $S Q I$ are the following: organic matter, $\mathrm{Ca}, \mathrm{Zn}$ and $\mathrm{CEC}$, in this contribution order. It is noteworthy that despite organic matter had a low weight in $S Q I$ model, a slight variation of this parameter represent a high change of $S Q I$ value.

\section{Conclusions}

The descriptive analysis of the soil quality indicators suggests that the Culiacan Valley soils are suitable for cultivation, with slight deficiencies of nutrients and salinity problems. Pearson correlation and PCA reflected relationships between some of the indicators analyzed, such as exchangeable cations $\left(\mathrm{Ca}^{2+}, \mathrm{Na}+, \mathrm{Fe}^{3+}\right.$ and $\left.\mathrm{Zn}^{2+}\right)$ and soluble cations and anions $\left(\mathrm{Ca}^{2+}, \mathrm{Na}^{+}, \mathrm{K}^{+}, \mathrm{Mg}^{2+}, \mathrm{SO}_{4}^{2-}\right)$. Based on the aforementioned statistical analysis, conductivity, $\mathrm{pH}$, organic matter, exchangeable cations, and soluble anions were identified as the most representative indicators of agricultural soils of Culiacan Valley.

According to $S Q I$ values obtained, soils of Culiacan Valley can be classified as medium and high quality. The good cation exchange capacity reflected a good 
Table 4. Soil quality index for soils of Culiacan Valley.

\begin{tabular}{cccc}
\hline Indicator & $W_{i}$ & $S_{i}$ & $S Q I$ Value \\
\hline pHsat & 0.01 & 0.91 & 0.23 \\
Organic Matter & 0.081 & 0.34 & 0.07 \\
$\mathrm{Na}^{\circ}$ & 0.11 & 0.40 & 0.05 \\
$\mathrm{Ca}^{\circ}$ & 0.12 & 0.61 & 0.05 \\
$\mathrm{Fe}^{*}$ & 0.14 & 0.38 & 0.01 \\
$\mathrm{Zn}^{*}$ & 0.09 & 0.59 & 0.01 \\
$\mathrm{CEC}$ & 0.09 & 0.75 & 0.26 \\
Electrical Conductivity (EC) & 0.35 & 0.90 & 0.09 \\
$S Q I$ & & & 0.642 \\
\hline
\end{tabular}

$*^{*}$ : Extractable ions; ${ }^{\circ}$ : Soluble ions.

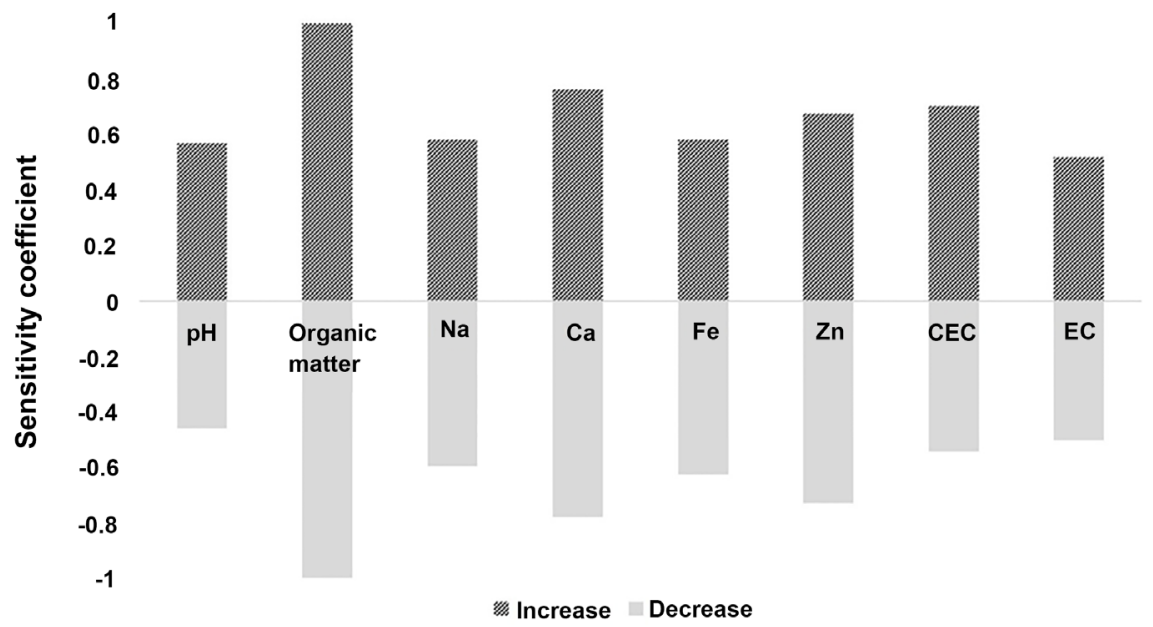

Figure 4. Sensitivity analysis for indicators of the soil quality index.

capacity of soil to exchange nutrients. However, $S Q I$ value was strongly influenced by organic matter, as it was demonstrated through a sensitivity analysis of soil quality model. High concentrations of sodium and a deficiency in the organic matter content are problems noticed in study area, which could be related to the use of fertilizers in this agricultural region. This situation can be solved with the implementation of better agricultural management practices according to climatic characteristics of the region.

Despite the importance of having soil quality information for agricultural purposes, soil quality description studies are scarce in tropical regions. In Sinaloa, as in many other agricultural regions of the world, it is essential to carry out soil quality studies, as more than half of its total population depends on agricultural activities. Historical soil quality data is essential in tropical regions in order to better understand this kind of ecosystems. A greater understanding of the soil conditions in these regions could mean the implementation of best management practices for soils, which in turn, would result in greater productivity and better 
yields, resulting in an economic growth of the region. At the same time, these studies could contribute the conservation and rational utilization of natural resources.

As a result of this work, soil quality index methodology is proposed to develop a robust SQI. A novel statistical methodology is proposed for the selection and weighting of these indicators in a region influenced by agricultural activities. Scientists and engineers commonly apply $S Q I$ directly without a preliminary analysis of its soil quality indicators. Application of the methodology discussed in this study can be used to increase the confidence in using SQI under different climatic and hydrologic conditions. This methodology may be applied to soils located in tropical, sub-tropical, and temperate regions. This tool would also increase the confidence of decision makers in soil quality indexes to help formulate effective soil management programmes.

\section{Acknowledgements}

The authors acknowledge to National Council of Science and Technology in Mexico (CONACYT) for supporting this research work in the call for 2014 Scientific Projects to Address National Problems (Proyectos de Desarrollo Científico para Atender Problemas Nacionales 2014-Ref. 248517).

\section{References}

[1] Schiefer, J., Laira, G. and Blum, W. (2015) Indicators for the Definition of Land Quality as a Basis for the Sustainable Intensification of Agricultural Production. International Soil and Water Conservation Research, 3, 42-49.

[2] Altamirano-Aguilar, A., Valdez-Torres, J.B., Valdez-Lafarga, C., León-Balderrama, J.I., Betancourt-Lozano, M. and Osuna-Enciso, T. (2017) Clasificación y evaluación de los distritos de riego en México con base en indicadores de desempeño. [Classification and Evaluation of the Irrigation Districts in Mexico Based on Performance Indicators.] Tecnología y Ciencias del Agua, 8, 79-99. https://doi.org/10.24850/j-tyca-2017-04-05

[3] Lal, R. and Stewart, B.A. (2010) Food Security and Soil Quality. CRC Press, Boca Raton, 416.

[4] Karlen, D.L., Mausbach, M.J., Doran, J.W., Cline, R.G., Harris, R.F. and Schuman, G.E. (1997) Soil Quality: A Concept, Definition and Framework for Evaluation. Soil Science Society of America Journal, 61, 4-10.

[5] Schloter, M., Dilly, O. and Munch, J.C. (2003) Indicators for Evaluating Soil Quality. Agriculture, Ecosystems and Environment, 98, 255-262.

[6] Shekhovtseva, O.G. and Mal'tseva, I.A. (2015) Physical, Chemical, and Biological Properties of Soils in the City of Mariupol, Ukraine. Eurasian Soil Science, 48, 1393-1400. https://doi.org/10.1134/S1064229315120145

[7] Ghaemi, M., Astaraei, A., Emami, H., Mahalati, M. and Sanaeinejad, S. (2014) Determining Soil Indicators for Soil Sustainability Assessment using Principal Component Analysis of Astan Quds-East of Mashhad Iran. Journal of Soil Science and Plant Nutrition, 14, 987-1004.

[8] Obade, V. and La, R. (2016) A Standardized Soil Quality Index for Diverse Field Conditions. Science of the Total Environment, 541, 424-434. 
[9] Delgado, E., Trejos, J., Villalobos, M., Martínez, G., Lobo, D., Rey, J., Rodríguez, G., Rosales, F. and Pocasangre, L. (2010) Determinación de un índice de calidad y salud de suelos para plantaciones bananeras en Venezuela. [Determination of an Index of Quality and Health of Soils for Banana Plantations in Venezuela.] Interciencia DEC, 35, 927-933.

[10] Prieto, J., Prieto, R., Acevedo, O. and Méndez, M. (2013) Indicadores e índices de calidad de los suelos (ICS) cebaderos del sur del estado de Hidalgo, México. [Soil Quality Indicators and Indexes (SQI) in the Southern of State of Hidalgo, Mexico.] Agronomía Mesoamericana, 24, 83-91. https://doi.org/10.15517/am.v24i1.9643

[11] Hinojoza-Castro, G.G. and Plata-Rocha, W. (2015) Change Analysis of Land Use and Urban Growth in the Municipalities of Culiacan and Navolato, Sinaloa, Mexico Using Statistical Techniques and GIS. Journal of Geographic Information System, 7, 620-630. https://doi.org/10.4236/jgis.2015.76050

[12] Pansu, J., Giguet-Covex, C. and Francesco-Ficetola, G. (2015) Reconstructing Long-Term Human Impacts on Plant Communities: An Ecological Approach Based on Lake Sediment DNA. Molecular Ecology, 24, 1485-1498.

[13] García-de la Parra, L.M., Cervantes-Mojica, L.J., González-Valdivia, C., Martínez-Cordero, F.J., Aguilar-Zárate, G., Bastidas-Bastidas, P. and Betancourt-Lozano, M. (2012) Distribution of Pesticides and PCBs in Sediments of Agricultural Drains in the Culiacan Valley, Sinaloa, Mexico. Archives of Environmental Contamination and Toxicology, 63, 323-336. https://doi.org/10.1007/s00244-012-9780-5

[14] Sanhouse-Garcia, A.J., Bustos-Terrones, Y., Rangel-Peraza, J.G., Quevedo-Castro, A. and Pacheco, C. (2016) Multi-Temporal Analysis for Land Use and Land Cover Changes in an Agricultural Region using Open Source Tools. Remote Sensing Applications: Society and Environment.

[15] Chi, C.-M. and Wang, Z.-C. (2010) Characterizing Salt-Affected Soils of Songnen Plain using Saturated Paste and 1:5 Soil-to-Water Extraction Methods. Arid Land Research and Management, 24, 1-11.

[16] Gelman, F., Binstock, R. and Halicz, L. (2012) Application of the Walkley-Black Titration for the Organic Carbon Quantification in Organic Rich Sedimentary Rocks. Fuel, 96, 608-610.

[17] Hanum, C., Rauf, A., Fazrin, D.A. and Habibi, A.R. (2016) Nitrogen, Phosphor, and Potassium Level in Soil and Oil Palm Tree at Various Composition of Plant Species Mixtures Grown. Earth and Environmental Science, 41. https://doi.org/10.1088/1755-1315/41/1/012008

[18] Askari, M. and Holden, N. (2014) Indices for Quantitative Evaluation of Soil Quality under Grassland Management. Geoderma, 230, 131-142.

[19] Bazhenov, M.A., Tikhova, V.D. and Fadeeva, V.P. (2016) Determination of Boron in Organic Compounds by Microwave Plasma-Atomic Emission Spectrometry. Journal of Analytical Chemistry, 71, 1089-1095. https://doi.org/10.1134/S1061934816090033

[20] Matin, N.H. and Jalali, M. (2017) The Effect of Waterlogging on Electrochemical Properties and Soluble Nutrients in Paddy Soils. Paddy and Water Environment, 15, 443-455.

[21] De Andrade, J.C., Andrekowisk Fioravanti, L.M. and de Abreu, M.F. (2005) Determination of Bicarbonate in Substrate Extracts using Back-Titration and the Gran Plot Approach. Communications in Soil Science and Plant Analysis, 36, 2359-2366. https://doi.org/10.1080/00103620500251153 
[22] Caballero, E.M.C., Víctor, H.Á.V. and Dos Santos, A.F. (2014) Determination of Sulphate by Turbidimetry in Acid Sulphate Soil. Acta Agronomica, 63, 44-49.

[23] Visconti, F., De Paz, J.M., Rubio, J.L. and Sánchez, J. (2011) Saltirsoil: A Simulation Model for the Mid to Long-Term Prediction of Soil Salinity in Irrigated Agriculture. Soil Use and Management, 27, 523-537. https://doi.org/10.1111/j.1475-2743.2011.00356.x

[24] Paz-Kagan, T., Shachak, M., Zaady, E. and Karnieli, A. (2014) A Spectral Soil Quality Index (SSQI) for Characterizing Soil Function in Areas of Changed Land Use. Geoderma, 230, 171-184.

[25] Cude, C.G. (2001) Oregon Water Quality Index: A Tool for Evaluating Water Quality Management Effectiveness. Journal of the American Water Resource Association, 37, 125-137.

[26] Biswas, S., Hazra, G., Purakayastha, T., Saha, N., Mitran, T., Roy, S., Basak, N. and Mandal, B. (2017) Establishment of Critical Limits of Indicators and Indices of Soil Quality in Rice-Rice Cropping Systems under Different Soil Orders. Geoderma, 292, 34-48.

[27] Vasu, D., Singh, S.K., Ray, S.K., Duraisami, V.P., Tiwary, P., Chandran, P., Nimkar, A.M. and Anantwar, S.G. (2016) Soil Quality Index (SQI) as a Tool to Evaluate Crop Productivity in Semi-Arid Deccan Plateau, India. Geoderma, 282, 70-79.

[28] Hajkowicz, S. (2006) Multi-Attributed Environmental Index Construction. Ecological Economics, 57, 122-139.

[29] Etebu, E. and Osborn, A.M. (2012) A Review of Indicators of Healthy Agricultural Soils with Pea Footrot Disease Suppression Potentials. Sustainable Agriculture Research, 1, 235-250.

[30] Mukhopadhyay, S., Masto, R., Yadav, A., George, J., Ram, L. and Shukla, S. (2016) Soil Quality Index for Evaluation of Reclaimed Coal Mine Spoil. Science of the Total Environment, 542, 540-550.

[31] FAO (2013) El manejo del suelo en la producción de hortalizas con buenas prácticas agrícolas. [Soil Management in the Production of Vegetables with Good Agricultural Practices.] Project TCP/PAR/3303. FAO, Roma.

[32] Lal, R. (2006) Encyclopedia of Soil Science. CRC Press, Boca Raton, 959-1923.

[33] Zhao, H. and Zhang, L. (2014) Effect of Course Content on Shear Behavior of Unsaturated Coarse Granular Soils. Canadian Geotechnical Journal, 51, 1371-1383. https://doi.org/10.1139/cgj-2012-0292

[34] Mokarram, M. and Najafi-Ghiri, M. (2016) Combination of Fuzzy Logic and Analytical Hierarchy Process Techniques to Assess Potassium Saturation Percentage of Some Calcareous Soils (Case Study: Fars Province, Southern Iran). Agriculture (Switzerland), 6, 59. https://doi.org/10.3390/agriculture6040059

[35] Ahmad, A.A., Fares, A., Farhat, D. and Jonathan, L. (2009) Nutrient Concentrations within and below Root Zones from Applied Chicken Manure in Selected Hawaiian Soils. Journal of Environmental Science and Health, 44, 828-843. https://doi.org/10.1080/03601230903238723

[36] Merrington, G. and Schoeters, I. (2010) Soil Quality Standards for Trace Elements. Derivation, Implementation and Interpretation. CRC Press, Boca Raton, 184. https://doi.org/10.1201/b10293

[37] Athokpam, H.S., Athokpam, H., Ghosh, G.K., Wani, S.H., Akoijam, S. and Ningthoujam, R. (2016) Evaluation of Some Soil Test Methods in Acid Soils for Available Phosphorus for Pea of Senapati District of Manipur (India). International Journal of 
Agriculture, Environment and Biotechnology, 9, 63-68.

https://doi.org/10.5958/2230-732X.2016.00010.3

[38] Serrano, J.M., Shahidian, S. and Marques da Silva, J. (2017) Spatial Variability and Temporal Stability of Apparent Soil Electrical Conductivity in a Mediterranean Pasture. Precision Agriculture, 18, 245-263.

https://doi.org/10.1007/s11119-016-9460-y

[39] Nell, J.P. and van Huyssteen, C.W. (2014) Soil Classification Groups to Quantify Primary Salinity, Sodicity and Alkalinity in South African Soils. South African Journal of Plant and Soil, 31, 117-125. https://doi.org/10.1080/02571862.2014.921941

[40] Pulido-Moncada, M., Ball, B., Gabriels, D., Lobo, D. and Cornelis, W. (2015) Evaluation of Soil Physical Quality Index $\mathrm{S}$ for Some Tropical and Temperate Medium-Textured Soils. Soil Science Society of America Journal, 79, 9-19. https://doi.org/10.2136/sssaj2014.06.0259

[41] Masto, R.E., Chhonkar, P.K., Purakayastha, T.J., Patra, A.K. and Singh, D. (2008) Soil Quality Indices for Evaluation of Long-Term Land Use and Soil Management Practices in Semi-Arid Sub-Tropical India. Land Degradation and Development, 19, 516-529. https://doi.org/10.1002/ldr.857

[42] Ortega, R. (2015) Análisis de suelo revisitado: Una herramienta esencial para el diagnóstico nutricional y el manejo integrado de la nutrición. [Revised Soil Analysis: An Essential Tool for Nutritional Diagnosis and Integrated Nutriotion Management.] Red Agrícola, Octubre, 2015, 78-82.

[43] Wu, T., Milner, H., Diaz-Perez, J. and Ji, P. (2015) Effects of Soil Management Practices on Soil Microbial Communities and Development of Southern Blight in Vegetable Production. Applied Soil Ecology, 91, 58-67.

[44] Shiri, J., Keshavarzi, A., Kisi, O., Iturraran-Viveros, U., Bagherzadeh, A., Mousavi, R. and Karimi, S. (2017) Modeling Soil Cation Exchange Capacity using Soil Parameters: Assessing the Heuristic Models. Computers and Electronics in Agriculture, 135, 242-251.

[45] Srinivasan, V., Thankamani, C.K., Dinesh, R., Kandiannan, K., Zachariah, T.J., Leela, N.K., Hamza, S., Shajina, O. and Ansha, O. (2016) Nutrient Management Systems in Turmeric: Effects on Soil Quality, Rhizome Yield and Quality. Industrial Crops and Products, 85, 241-250.

[46] Shukla, A.K., Behera, S.K., Lenka, N.K., Tiwari, P.K., Prakash, C., Malik, R.S., Sinha, N.K., Singh, V.K. and Chaudhary, S.K. (2016) Spatial Variability of Soil Micronutrients in the Intensively Cultivated Trans-Gangetic Plains of India. Soil and Tillage Research, 163, 282-289.

[47] Gutierrez-Gines, M., Hernandez, A. and Pastor, J. (2016) Impacts of Soil-Soluble Anions on Wild and Cultivated Herbaceous Species: Implications for Soil Phytoremediation. Journal of Soil Science and Plant Nutrition, 16, 423-437.

[48] Seco, A., Miqueleiz, L., Prieto, E., Marcelino, S., Garcia, B. and Urmeneta, P. (2017) Sulfate Soils Stabilization with Magnesium-Based Binders. Applied Clay Science, 135, 457-464.

[49] Mukherjee, A. and Lal, R. (2014) Comparison of Soil Quality Index using Three Methods. PLOS ONE, 9, e105981. https://doi.org/10.1371/journal.pone.0105981

[50] Mukhopadhyay, S., Maiti, S. and Masto, R. (2014) Development of Mine Soil Quality Index (MSQI) for Evaluation of Reclamation Success: A Chronosequence Study. Ecological Engineering, 71, 10-20. 
[51] Kasperski, A. and Zieliński, P. (2016) Robust Discrete Optimization under Discrete and Interval Uncertainty: A Survey. In: Doumpos, M., Zopounidis, C., Grigoroudis, E., Eds., Robustness Analysis in Decision Aiding, Optimization, and Analytics, International Series in Operations Research and Management Science, Vol. 241, Springer, Cham. 